\title{
KUALITAS BELANJA DAERAH DAN HUBUNGANNYA DENGAN KINERJA PEMBANGUNAN DI PROVINSI BANTEN
}

\author{
Sri Wahyuni ${ }^{1}$, Bambang Juanda ${ }^{2}$, Idqan Fahmi ${ }^{2}$ \\ ${ }^{1}$ Mahasiswa Program Magister Ilmu Ekonomi, FEM IPB \\ ${ }^{2}$ Staff Pengajar FEM IPB
}

\begin{abstract}
This study aims to analyze the relevant indicators of spending quality in measuring the quality of regional spending as well as the relationship between the quality of regional spending and the development performance of the regencies/cities of Banten Province. This study uses secondary data from the governance, financial and performance development of the districts/cities of Banten Province between 2009 2013. The Data are analyzed using Partial Least Squares Structural Equation Model (PLS-SEM) using SmartPLS software version 2.0 \& SmartPLS version 3.0. The Results show that there are 21 indicators out of 40 indicators that are relevant in measuring the quality of the districts/cities spending in Banten Province. The change of the spending quality map from 2009 to 2013 shows that the quality of North Banten (Tangerang Regency, Tangerang City, Tangerang Selatan, Serang Regency, Serang City and Cilegon City) is better than South Banten (Pandeglang and Lebak). In addition, the estimation results from the model used indicate that the quality of the region spending of Banten Provinve has a positive relationship with the performance of development with the value of the indicator 0,678.
\end{abstract}

Keywords : Development Performance, PLS-SEM, Spending Quality

\section{PENDAHULUAN}

Sistem pemerintah daerah di Indonesia telah menganut sistem otonomi daerah, dimana terjadinya pengalihan kekuasaan dari pemerintah pusat ke daerah (Hakim 2013). Otonomi daerah merupakan wujud dari dianutnya asas desentralisasi. Hal ini diterapkan untuk memberikan pelayanan yang maksimal kepada masyarakat. Dalam penyelenggaraannya, pemerintah daerah harus memperhatikan efisiensi dan efektivitas serta memperhatikan pemerataan pembangunan antar daerah. Salah satunya dengan cara memaksimalkan potensi dan keanekaragaman yang dimiliki oleh setiap daerah dalam menghadapai peluang dan tantangan persaingan global.

Berdasarkan Undang-Undang (UU) Nomor 33 Tahun 2004 tentang dana perimbangan keuangan, yang termasuk kedalam dana perimbangan keuangan yaitu Dana Alokasi Umum (DAU), Dana Alokasi Khusus (DAK) dan Dana Bagi Hasil (DBH) antara pemerintah pusat dan pemerintah daerah untuk memaksimalkan pelayanannya kepada masyarakat sesuai dengan prioritas kebutuhan masyarakat. Dalam dana perimbangan tersebut, biasanya pemerintah daerah selalu mempermasalahkan terkait kuantitas transfer dana perimbangan dari pusat ke daerah yang dirasa berbeda antar daerah. Hal ini dipicu oleh kondisi daerah tertentu 
yang lebih maju dibandingkan daerah lainnya. Padahal proporsi dana perimbangan yang ditransfer dari pusat ke daerah dilakukan sesuai dengan kebutuhan daerah masing-masing.

Hasil dari kesuksesan pembangunan disuatu daerah bergantung kepada kualitas sistem pengelolaan belanja yang dilakukan oleh pemerintah daerah tersebut. Menurut Juanda et al. (2013a), belanja pemerintah daerah dapat dikatakan berkualitas apabila anggaran belanja tersebut dialokasikan berdasarkan prioritas pembangunan daerah dengan memperhatikan aspekaspek berikut ini, diantaranya yaitu efisien dan efektif, tepat waktu, transparan dan akuntabel. Apabila dana belanja daerah digunakan secara berkualitas, hal ini dapat berpengaruh positif terhadap kinerja pembangunan, khususnya dalam mengurangi tingkat kemiskinan, pengangguran dan ketimpangan.

Secara umum, realisasi proporsi belanja daerah kabupaten/kota Provinsi Banten pada tahun 2009-2013 menunjukkan bahwa proporsi paling besar dialokasikan untuk belanja pegawai yang terus mengalami peningkatan selama kurun waktu tersebut dibandingkan dengan proporsi belanja modal serta belanja barang dan jasa. Kondisi ini didukung oleh penelitian yang dilakukan oleh Juanda (2016) yang menyatakan bahwa porsi belanja pegawai negeri sipil kabupaten/kota Provinsi Banten dalam APBD-nya relatif cukup besar, yaitu sebesar 50\% dari APBD.

Beberapa kabupaten/kota yang memiliki porsi belanja pegawai negeri sipil sebesar $50 \%$ diantaranya adalah Kabupaten Pandeglang, Kabupaten Lebak, Kabupaten Serang, dan Kota Serang. Hal ini menunjukkan bahwa Pemerintah Daerah (Pemda) Banten masih berfokus pada masalah administrasi serta belum maksimal untuk pelayanan publik dan infrastruktur. BPK (2015) juga menyatakan bahwa Provinsi Banten sejak tahun 2013 mendapatkan predikat "Tidak Menyatakan Pendapat (TMP)" atau disclaimer. Predikat ini diterbitkan karena pihak auditor belum bisa memastikan kewajaran laporan keuangan, dimana pihak audit terkendala mendapatkan informasi utuh untuk menyimpulkan atau menyatakan laporan keuangan tersebut wajar. Hal ini terjadi akibat dari pembatasan ruang lingkup oleh Pemda Banten kepada audit dalam memperoleh informasi.

Berdasarkan penjelasan di atas, penulis mencoba untuk membahas kualitas belanja daerah dan keterkaitanya dengan kinerja pembangunan di Provinsi Banten. Variabel dari kualitas belanja daerah yang dimasukkan dalam penelitian ini dirumuskan berdasarkan teori yang disusun oleh Juanda et al. (2013a).

Penerapan dari teori tersebut juga dilakukan dalam penelitian Heriwibowo (2016) dimana indikator kualitas belanja daerah dapat dilihat dari prioritas, alokasi dana, efektif dan efisien, akuntabilitas dan tepat waktu. Selain itu, dalam penelitian tersebut dijelaskan pula hubungan kualitas belanja daerah dengan kinerja pem-bangunan yang dilihat dari tingkat pengangguran, indeks gini, pertumbuhan ekonomi, PDRB perkapita dan Indeks Pembangunan Manusia (IPM). Sehingga, pada penelitian ini akan dianalisis indikator-indikator yang relevan dalam mengukur kualitas belanja daerah di Provinsi Banten serta keterkaitan antara indikator kualitas belanja daerah dengan kinerja pembangunan di Provinsi Banten. 


\section{TINJAUAN PUSTAKA}

\section{Pembangunan Ekonomi}

Pembangunan ekonomi secara tradisional memiliki arti peningkatan secara terus menerus pada Gross Domestic Product atau Produk Domestik Bruto suatu negara sedangkan secara daerah makna pembangunan yang tradisional difokuskan pada peningkatan Produk Domestik Regional Bruto suatu provinsi, kabupaten atau kota. Sedangkan pembangunan modern mengedepankan penurunan tahta pertumbuhan ekonomi, pengentasan kemiskinan, pengurangan ketimpangan distribusi pendapatan, dan penurunan tingkat pengangguran yang ada. Sedangkan menurut Todaro dan Smith (2006) pembangunan secara tradisional adalah kapasitas dari sebuah perekonomian nasional yang kondisi ekonomi awalnya kurang lebih bersifat statis dalam kurun waktu yang cukup lama untuk menciptakan dan mempertahankan kenaikan pendapatan nasional bruto atau GNI (Gross National Income).

Pada akhir tahun 1960 banyak negara berkembang menyadari bahwa pertumbuhan ekonomi tidak identik dengan pembangunan ekonomi karena pertumbuhan ekonomi yang tinggi yang bisa mencapai negara-negara maju pada tahap awal pembangunan memang dapat dicapai tapi dibarengi dengan munculnya masalah-masalah seperti pengangguran, kemiskinan di pedesaan, distribusi pendapatan yang timpang dan ke-tidakseimbangan struktural.

\section{Konsep Desentralisasi}

Reformasi sistem politik dilakukan beriringan dengan jatuhnya rezim orde baru yaitu sistem pemerintah yang sentralistik digantikan sistem pemerintah desentralistik karena sistem tersebut sudah tidak bisa lagi menampung aspirasi masyarakat di daerah, sehingga dilaksanakanlah sistem desentralisasi dimana pemberian otonomi kepada daerah-daerah untuk mengelola dan mengatur sendiri pemerintahannya sesuai dengan aspirasi masyarakat, kebutuhan daerahnya dan peraturan perundang-undangan dengan menekankan prinsip bertanggung jawab, transparansi dan akuntabilitas (Adisasmita, 2011). Rondinelli et al. (1986) mendefinisikan desentralisasi sebagai pengalihan tanggung jawab dan wewenang untuk perencanaan, manajemen, penggalangan sumber daya dan peningkatan alokasi serta fungsi dari pemerintah pusat dan lembagalembaganya ke unit kementrian pemerintah pusat atau lembaga, unit bawahan atau tingkat pemerintah daerah, otoritas semi otonom publik atau perusahaan, atau organisasi non pemerintah seperti organisasi swasta atau sukarela.

Desentralisasi juga dapat didefinisikan sebagai suatu situasi dimana barang dan jasa publik yang disediakan berdasarkan preferensi individusi melalui mekanisme pasar, teori pilihan publik berpendapat bahwa dalam kondisi pilihan cukup bebas, penyediaan beberapa barang publik lebih efisien secara ekonomi ketika sejumlah lembaga daerah terlibat dalam penyediaan barang dibandingkan hanya disediakan oleh pemerinta pusat (Ostrom et al.,, 1961).

Selain itu, desentralisasi adalah ukuran yang paling dianjurkan untuk meningkatkan penyediaan kesehatan dan pendidikan di negara berkembang. Sehingga dengan adanya pelimpahan kekuasaan dan sumberdaya kepada pemerintah daerah diharapkan dapat meningkatkan akuntabilitas pegawai negeri serta dapat meningkatkan pelayanan publik dengan memberikan 
respon yang cepat atas kebutuhan masyarakat (Faguet, 2008).

\section{Keuangan Pemerintah Daerah}

Keuangan daerah merupakan semua hak dan kewajiban daerah dalam rangka penyelenggaraan pemerintah daerah yang dapat dinilai dengan uang termasuk didalamnya segala bentuk kekayaan yang berhubungan dengan hak dan kewajiban daerah tersebut dalam kerangka Anggaran Pendapatan dan Belanja Daerah (Adisasmita, 2011). Dimana tanggungjawab keuangan merupakan inti dari konsep desentralisasi, diantara pengaturan pembiayaan yang harus dipertimbangkan adalah : (1) Penerapan retribusi; (2) penerapan pungutan perbaikan; (3) Adopsi pendanaan bersama; (4) Perluasan sumber pendapatan umum untuk barang publik; (5) mengalokasikan pendapatan khusus atau dana dari sumber-sumber pendapatan tertentu seperti pajak, bea masuk, biaya dan denda, pajak hiburan atau entertainment yang digunakan untuk infrastukur dan layanan pedesaan; (6) Mobilisasi sumberdaya pemerintah (melalui jaminan pelayanan atau kredit bersubsidi) agar individ dapat memperoleh pinjaman dari penyedia swasta; (7) pertukaran jasa atau tenaga kerja dari penerima manfaat dengan imbalan perpanjangan layanan atau infrastruktur oleh pemerintah daerah; (8) mengumpulkan dana dalam kegiatan sosial seperti pameran komunitas yang akan digunakan untuk dana sosial; dan (9) penciptaan kegiatan produktif masyarakat skala kecil untuk mengumpulkan dana bagi penyediaan layanan dan pembangunan infrastruktur dan pe-meliharaan (Rondinelli et al., 1986).

\section{Laporan Pemeriksaan Keuangan}

Berdasarkan Undang-Undang Republik Indonesia Nomor 15 tahun 2004 tentang pemeriksaan pengelolaan dan tanggung jawab keuangan negara dimana dalam undang-undang ini dijelaskan bahwa pemeriksaan adalah proses identifikasi masalah, analisis dan evaluasi yang dilakukan secara independen, objektif, dan profesional berdasarkan standar pemeriksaan, untuk menilai kebenaran, kecermatan, kredibilitas, dan keandalan informasi mengenai pengelolaan dan tanggung jawab ke-uangan negara. Pemeriksaan ini dilakukan oleh Badan Pemeriksa Keuangan (BPK) dimana pemeriksaan dilakukan kepada pejabat atau lembaga perwakilan yang diberikan tanggung jawab dalam pengelolaan keuangan negara sesuai dengan kedudukan dan kewenangannya yang meliputi perencanaan, pelaksanaan, dan pertanggung jawaban. Dengan mengacu pada standar pemeriksaan yaitu patokan untuk melakukan pemeriksaan pengelolaan dan tanggung jawab keuangan negara yang meliputi standar umum, standar pelaksanaan pemeriksaan, dan standar pelaporan yang wajib dipedomani oleh BPK.

\section{Konsep Belanja Pemerintah Daerah}

Belanja Pemerintah Daerah adalah seluruh pendapatan daerah yang diperoleh maupun bantuan dari transfer pemerintah pusat, pemerintah propinsi dan sebagainya akan digunakan untuk membiayai semua pengeluaran melalui pos belanja daerah maupun pengeluaran pembiayaan. Menurut UU nomor 23 Tahun 2014 tentang pemerintah daerah, belanja daerah adalah semua kewajiban daerah yang diakui sebagai pengurang nilai kekayaan bersih dalam periode anggaran yang bersangkutan. Dimana belanja daerah ini sangat membantu 
dalam pelaksanaan adanya otonomi daerah.

\section{Konsep dan Indikator Kualitas Belanja Daerah}

Menurut Juanda et al. (2013) belanja berkualitas adalah belanja yang dialokasikan berdasarkan prioritas pembangunan daerah yang dilakukan secara efisien dan efektif, tepat waktu, transparan dan akuntabel. Pernyataan prioritas daerah bisa berbeda antara daerah tergantung kondisi dan kebutuhan masing-masing daerah yang perlu diprioritaskan.

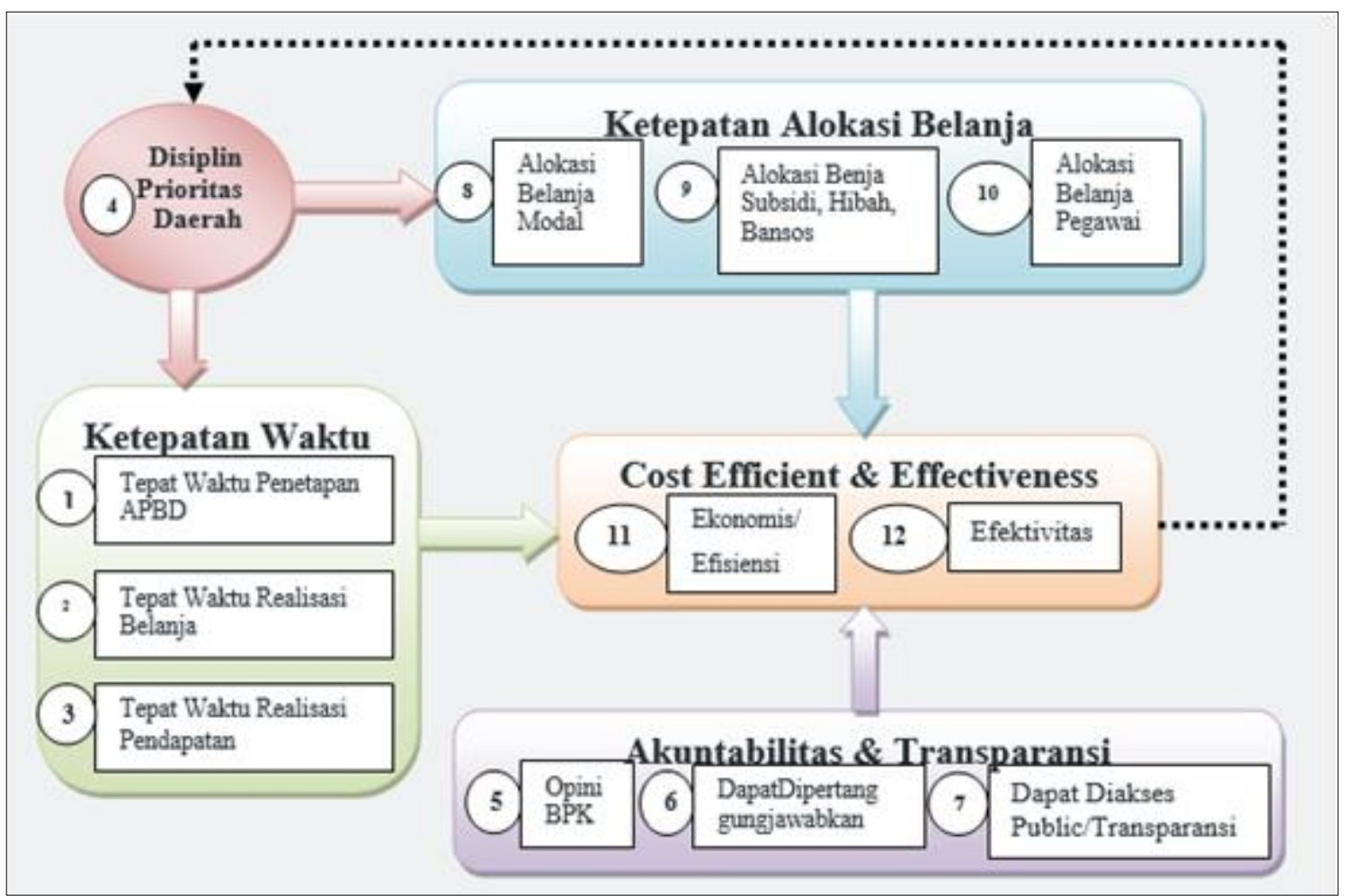

Sumber : Juanda et al. (2013)

Gambar 1 Keterkaitan Atribut dan Indikator Kualitas Belanja Daerah

Pada Gambar di atas menunjukkan lima latent variable/atribut kualitas belanja daerah dan indikatornya yaitu prioritas belanja daerah yang dilaksanakan dengan disiplin tinggi yang akan mempengaruhi ketepatan alokasi belanja dengan indikator alokasi belanja modal, alokasi belanja subsidi, hibah, bansos serta alokasi belanja pegawai. Kemudian prioritas belanja daerah yang dilaksanakan dan dianggarkan dengan baik tidak akan berarti apabila tidak disusun tepat waktu dengan indikator tepat waktu penetapan APBD, tepat waktu realisasi belanja dan tepat waktu realisasi pendapatan. Belanja daerah juga harus dilaksanakan depan prinsip akuntabilitas dan transparan atas penggunaan anggaran dengan indikator opini BPK, dapat dipertanggungjawabkan serta dapat diakses oleh publik atau transparansi. Selanjutnya belanja daerah yang berkualitas harus dilaksanakan dengan efisien dan efektif.

\section{Penelitian Terdahulu}

Penelitian mengenai kualitas belanja daerah dilakukan pertama kali di 
Indonesia oleh Juanda et al. (2013) dalam "Evaluasi Regulasi Pengelolaan Keuangan Daerah dan Pengaruhnya terhadap Upaya Peningatan Kualitas Belanja Daerah". Kemudian hasilnya disimpulkan bahwa belanja berkualitas adalah belanja yang dialokasikan berdasarkan prioritas pembangunan daerah yang dilakukan secara efisien dan efektif, tepat waktu, transparan dan akuntabel.

Selanjutnya konsep kualitas belanja yang sudah dirumuskan oleh Juanda di lakukan penelitian lanjutan oleh Heriwibowo (2016) membahas mengenai Kajian Kualitas Belanja Daerah: Dinamika dan Pengukurannya dalam Pembangunan Wilayah di Indonesia. Hasilnya menunjukkan bahwa perlu adanya peningkatan pemerataan kemandirian fiskal dengan mendorong provinsi yang memiliki PAD yang kecil. Selanjutnya perlu peningkatan akuntabilitas belanja pegawai dalam peningkatan kualitas pelayanan publik, pencegahan korupsi dan peningkatan kinerja pembangunan daerah.

Dewi (2015) menganalisis kinerja pembangunan daerah suatu evaluasi terhadap kursus keuangan daerah. Dimana permasalahan yang dihadapi menunjukkan bahwa kualitas LKPD belum mencapai opini yang diharapkan yaitu Wajar Tanpa Pengecualian (WTP), dalam rangka meningkatkan kualitas laporan keuangan dan kinerja pembangunan yang baik perlu dikelola sumberdaya manusia yang kompeten. Pengelolaan keuangan yang baik menekankan perencanaan dan penganggaran berdasarkan kriteria belanja berkualitas sehingga pemerintah menyelenggarakan kursus keuangan daerah untuk meningkatkan kinerja aparat daerah di bidang pengelolaan keuangan.
Agustina (2013) menganalisis kinerja pengelolaan keuangan daerah dan tingkat kemandirian daerah di era otonomi daerah studi kasus kota Malang tahun anggaran 2007 sampai dengan 2011. Tujuan penelitiannya untuk mengetahui kinerja pengelolaan keuangan daerah dan tingkat kemandirian kota Malang. Alat analisa yang digunakan untuk mengukur kinerja pengelolaan keuangan daerah dan tingkat kemandirian kota Malang adalah rasio kemandirian keuangan daerah, rasio efektivitas, rasio efisiensi, rasio aktivitas dan rasio pertumbuhan. Dari hasil analisis rasio keuangan dapat disimpulkan bahwa secara umum kinerja pengelolaan keuangan daerah dan tingkat kemandiria kota Malang yang terus membaik. Hal tersebut dapat terlihat dari beberapa rasio kinerja keuangan daerah yaitu rasio kemandirian keuangan daerah, rasio efektivitas, dan rasio efisiensi yang terus meningkat dan berpengaruh baik terhadap kemandirian daerahnya meskipun ada beberapa rasio kinerja keuangan daerah yang menurun.

Pelaksanaan desentralisasi fiskal terhadap pemerataan kemampuan keuangan dan kinerja pembangunan di daerah studi kasus Kabupaten/Kota di Provinsi Banten. Hasil analisis menunjukkan bahwa pengalokasian DAU belum sepenuhnya menunjukkan peranan DAU sebagai mediasi pemerataan kemampuan keuangan antar daerah. Adapun peranan DAU di wilayah Banten selama tahun 2001 sampai dengan 2005 adalah meningkatkan pemerataan kemampuan keuangan daerah. 


\section{METODE PENELITIAN}

\section{Jenis dan Sumber Data}

Jenis data yang digunakan dalam penelitian ini adalah data sekunder yang mencakup data indikator kualitas belanja daerah di delapan kabupaten/kota Provinsi Banten tahun anggaran 2009 sampai dengan 2013. Provinsi Banten terdiri dari empat kabupaten dan empat kota yaitu Kabupaten Pandeglang, Kabupaten Lebak, Kabupaten Tangerang, Kabupaten Serang, Kota Tangerang, Kota Cilegon, Kota Serang, dan Kota Tangerang Selatan. Data yang digunakan dalam penelitian ini diperoleh dari Dirjen Otonomi Daerah Kementrian Dalam Negeri, Direktorat Jenderal Perimbangan Keuangan (DJPK) Kementrian Keuangan dan Badan Pusat Statistik (BPS).

Data indikator menggunakan skala likert: 4 (sangat tinggi); 3 (tinggi); 2 (sedang) dan 1 (rendah). Jangkauan skala ini sama dengan nilai skor yang digunakan Kementrian Dalam Negeri untuk mengevaluasi penyelenggaraan pemerintah daerah di Indonesia. Konversi data ke dalam skala likert dengan ketentuan berikut:

- Skor 4 untuk nilai data yang lebih besar dari $1,25 \mathrm{x}$ nilai rata-rata normalisasi;

- Skor 3 untuk nilai data antara nilai rata-rata normalisasi hingga $1,25 \mathrm{x}$ nilai rata-rata normalisasi;

- Skor 2 untuk nilai lebih besar dari 0,75 x nilai rata-rata normalisasi;

- Skor 1 untuk nilai sama dengan atau lebih kecil dari $0,75 \times$ nilai rata-rata normalisasi

- Indikator yang sifat capaian kinerjanya semakin kecil maka semakin baik, seperti tingkat kemiskinan, buta huruf, indeks gini dan pengangguran maka skor dan interval nilai susunnya dibalik.

\section{Metode Analisis Data}

Penelitian tentang kualitas belanja daerah ini menggunakan model persamaan struktural (struktural equation model/SEM) dengan pendekatan perhitungan partial least squares (PLS-SEM). Model persamaan struktural ini memiliki dua fitur utama yaitu model struktural dan model pengukuran. Jenis data yang digunakan dalam metode PLS-SEM adalah data dengan skala ordinal dan kontinyu, dimana data tidak diharuskan data terdistribusi normal. Perangkat lunak yang digunakan dalam perhitungan PLS-SEM yaitu SmartPLS versi 2.0 dan SmartPLS versi 3.0.

Evaluasi model dilakukan dua tahap, yaitu evaluasi model pengukuran dan evaluasi model struktural (Hair et al. 2011). Evaluasi model pengukuran dilakukan uji validitas dan uji reliabilitas indikator. Setelah itu, dilakukan perhitungan untuk menentukan nilai Construk Reliability (CR), dimana untuk penelitian yang bersifat eksplanatori maka nilainya berkisar antara 0,60 sampai 0,70, Apabila nilainya kurang dari 0,60 . Hal ini mengindikasikan bahwa realibilitas buruk. Selanjutnya penilaian terhadap validitas model difokuskan terhadap validitas konvergen dan diskriminan. Validitas konvergen ditunjukkan oleh Average Variance Extracted (AVE) yang sebaiknya bernilai 0,50. Apabila nilai AVE di atas 0,50, hal ini mengindikasikan bahwa lebih dari separuh variasi konstruk dapat menjelaskan varian indikator (Heriwibowo, 2016). 


\section{HASIL DAN PEMBAHASAN}

\section{Identifikasi Model Kualitas Belanja}

Model kualitas belanja daerah terdiri dari 5 kontruk dan 40 indikator yang merefleksikan konstruk. Perhitungan parameter model lengkap awal dilakukan dengan model PLSSEM yang akan menghasilkan parameter indikator. Kemudian dilakukan seleksi indikator yang tidak memenuhi persyaratan reliabilitas indikator (loading factor > 0,4) dan valid (nilai t-hitung > 1,96). Estimasi parameter model kualitas belanja daerah menggunakan SmartPLS 3.0 dan SmartPLS 2.0, sehingga akan dihasilkan indikator dominan yang mendukung kualitas belanja daerah kabupaten/kota Provinsi Banten. loading factor yang tidak memenuhi kriteria sebaiknya dihilangkan, dimana eliminasi ini bisa meningkatkan nilai reliabilitas dan validitas konstruk (Hair et al., 2011).

Hasil pengujian reliabilitas dan validitasmenunjukkan bahwa secara keseluruhan terpilih 21 indikator reflektif dimana hampir semua indikator tersebut memenuhi persyaratan reliabilitas (loading > 0,4) dan validitas (t-hitung > 1,65). Indikator tersebut terdiri dari 3 indikator pengukuran konstruk prioritas (A3, A4, A5), 3 indikator pengukuran konstruk alokasi (B2, B3, B4), 3 indikator pengukuran konstruk waktu (C2, C3, C4), 4 indikator pengukuran konstruk akuntabilitas (D1, D2, D3, D4), 5 indikator pengukuran konstruk efektivitas (E1, E2, E3, E4, E5), dan 3 indikator pengukuran konstruk kinerja pembangunan (F3a, F5a, F6a).

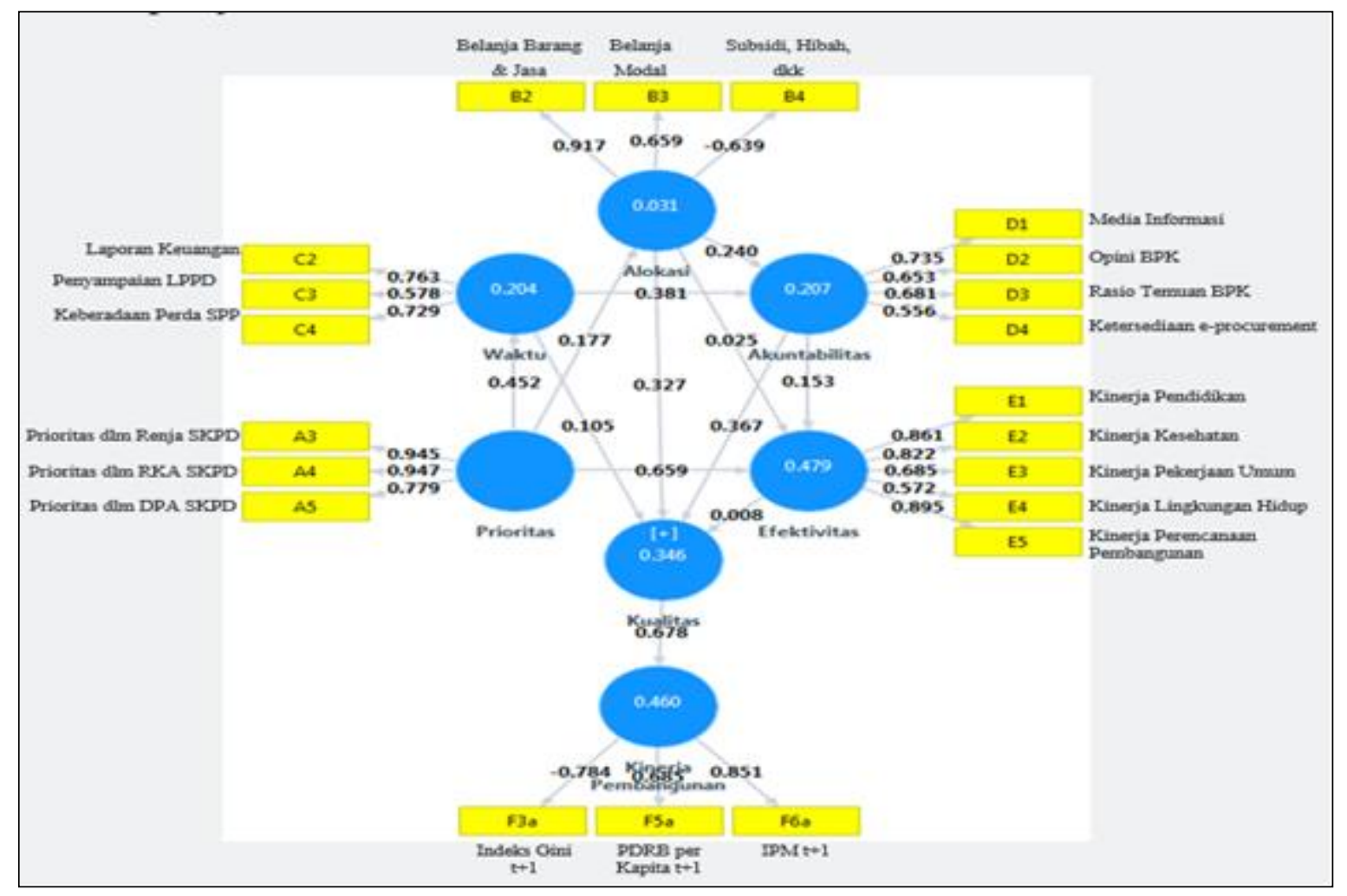

Sumber : Hasil olah smartPLS 3.0

Gambar 2 Model Kualitas Belanja Terpilih di Kabupaten/Kota Provinsi Banten 
Selain ukuran reliabilitas dan validitas indikator, ukuran yang perlu diperhatikan juga adalah ukuran reliabilitas dan validitas konstruk. Ukuran reliabilitas konstruk pada penelitian ini ditunjukkan oleh $\mathrm{CR}$. Hasil estimasi CR menunjukkan bahwa semua konstruk kualitas belanja memiliki nilai CR di atas 0,60 sehingga dapat disimpulkan bahwa hampir semua konstruk reliabel atau memenuhi uji reliabilitas, kecuali konstruk alokasi dan kinerja pembangunan. Tahap pengujian selanjut-nya adalah menilai validitas dari konstruk kualitas belanja daerah dengan melihat nilai AVE yang harus lebih besar dari 0,50. Hasil estimasi menunjukkan bahwa hanya konstruk akuntabilitas dan waktu yang memiliki
AVE di bawah 0,50. Sedangkan konstruk prioritas, alokasi, efektivitas dan kinerja pembangunan memiliki AVE di atas 0,50 sehingga memenuhi persyaratan validitas konvergen dan reliabilitas.

\section{Model Pengukuran Kualitas Belanja Daerah}

Model pengukuran kualitas belanja daerah dibentuk dari nilai loading factor yang merupakan koefisien regresi pada persamaan model. Persamaan model menunjukkan bahwa indikator kualitas belanja sebagai indikator reflektif yang ditentukan oleh karakteristik konstruk (Heriwibowo 2016).

Tabel 1 Model Pengukuran Kualitas Belanja Daerah

\begin{tabular}{|c|c|c|}
\hline No & Nama Model & Persamaan Model \\
\hline \multirow{3}{*}{ A } & Pengukuran Prioritas Belanja & A3 $=0,945$ Prioritas $+0,085$ \\
\hline & & A $4=0,947$ Prioritas $+0,086$ \\
\hline & & A5 $=0,779$ Prioritas $+0,152$ \\
\hline \multirow[t]{3}{*}{ B } & Pengukuran Alokasi Belanja & B2=0,917Alokasi+0,627 \\
\hline & & $\mathrm{B} 3=0,659$ Alokasi $+0,378$ \\
\hline & & B4=-0,639Alokasi+0,624 \\
\hline \multirow[t]{3}{*}{$\mathrm{C}$} & Pengukuran Waktu Belanja & $\mathrm{C} 2=0,763 \mathrm{Waktu}+0,257$ \\
\hline & & $\mathrm{C} 3=0,578 \mathrm{Waktu}+0,359$ \\
\hline & & $\mathrm{C} 4=0,729 \mathrm{Waktu}+0,373$ \\
\hline \multirow[t]{4}{*}{$\mathrm{D}$} & Pengukuran Akuntabilitas Belanja & $\mathrm{D} 1=0,735$ Akuntabilitas $+0,263$ \\
\hline & & $\mathrm{D} 2=0,653$ Akuntabilitas $+0,320$ \\
\hline & & D3 $=0,681$ Akuntabilitas $+0,338$ \\
\hline & & D4=0,556Akuntabilitas $+0,309$ \\
\hline \multirow[t]{6}{*}{$\mathrm{E}$} & Pengukuran Efektivitas Belanja & $\mathrm{E} 1=0,861$ Efektivitas $+0,122$ \\
\hline & & $\mathrm{E} 2=0,822$ Efektivitas $+0,084$ \\
\hline & & $\mathrm{E} 3=0,685$ Efektivitas $+0,106$ \\
\hline & & $\mathrm{E} 4=0,572$ Efektivitas $+0,204$ \\
\hline & & $\mathrm{E} 5=0,895$ Efektivitas $+0,060$ \\
\hline & & $\mathrm{F} 3 \mathrm{a}=-0,784$ Kinerja \\
\hline \multirow[t]{5}{*}{$\mathrm{F}$} & Pengukuran Kinerja Pembangunan & Pembangunan $+0,299$ \\
\hline & & F5a $=0,685$ Kinerja Pembangunan \\
\hline & & $+0,233$ \\
\hline & & $\mathrm{F} 6 \mathrm{a}=0,851$ Kinerja \\
\hline & & Pembangunan $+0,275$ \\
\hline
\end{tabular}

Sumber : Hasil Output SmartPLS v.3.0 


\section{Evaluasi Kualitas Belanja di Kabupaten/Kota Provinsi Banten}

\section{Prioritas Belanja}

Belanja yang berkualitas akan tercipta dari pengeluaran anggaran sesuai dengan prioritas pembangunan yang sudah direncanakan. Prioritas merupakan faktor terbesar dari kualitas belanja, jika dilihat dari nilai CR sebesar $92 \%$.

Persentase kabupaten/kota berdasarkan score variabel prioritas belanja. Pada tahun 2012 terdapat $62,5 \%$ kabupaten/kota yang masuk dalam kategori sangat tinggi, hal ini menunjukkan banyak daerah yang memiliki prioritas program pembangunan daerah senantiasa konsisten, sejalan dan selaras dengan kebijakan pemerintah pusat dan pemerintah provinsi. Namun, masih ada daerah yang masuk kategori rendah sebanyak $37,5 \%$ yaitu Kabupaten Pandeglang, Kabupaten Lebak dan Kota Serang. Hal ini menunjukkan bahwa prioritas pembangunan pada ketiga daerah tersebut kurang optimal sesuai dengan kebutuhan daerahnya. Sebagai contoh, Kabupaten Pandeglang memiliki potensi pada sektor pariwisata dan pertanian, tetapi belum ada infrastruktur yang mendukung dalam meningkatkan produktivitas pertanian serta daya tarik wisatawan untuk berkunjung.

Apabila infrastruktur untuk mendukung kedua sektor tersebut diprioritaskan, maka multiplier effect akan sangat besar terhadap pertumbuhan ekonomi dan kesejahteraan masyarakat Kabupaten Pandeglang. Selanjutnya, Kabupaten Lebak memiliki dana yang tidak terserap setiap tahunnya rata-rata sebesar 58\% terhadap total SiLPA. Hal ini menunjukkan bahwa pemerintah Kabupaten Lebak harus meningkatkan prioritas alokasi anggaran belanja, sehingga dana yang sudah dianggarkan terserap secara optimal. Sedangkan untuk Kota Serang pada tahun 2012 merupakan masa perbaikan infrastuktur wilayah guna memenuhi fungsi kota.

\section{Alokasi Belanja}

Alokasi belanja daerah sangat menentukan tingkat pemerataan perekonomian di daerah dimana porsi belanja modal yang produktif harus lebih besar dibandingkan porsi alokasi dana untuk subsidi dan belanja pegawai karena akan berdampak secara langsung terhadap perekonomian (Juanda et al. 2013b). Alokasi mempunyai pengaruh sebesar $40 \%$ terhadap kualitas belanja. Indikator alokasi belanja yang berpengaruh terhadap kualitas belanja yaitu belanja barang dan jasa, belanja modal serta belanja subsidi dan hibah. Salah satu indikator yang memiliki nilai loading faktor tertinggi adalah belanja barang dan jasa. Semakin tinggi belanja barang dan jasa, maka semakin tidak efisien. Tetapi, aktivitas belanja pemerintah terhadap barang dan jasa akan berdampak terhadap kesejahteraan masyarakat, sehingga belanja pemerintah berkualitas.

Persentase alokasi belanja daerah setiap tahunnya mengalami penurunan. Pada tahun 2009 hingga 2010 hanya 12.5\% kabupaten/kota Provinsi Banten yang masuk kategori sangat tinggi yaitu Kota Cilegon. Hal ini berarti, Kota Cilegon telah mengalokasikan dananya sudah tepat sasaran sesuai dengan kebutuhan daerahnya. Pada tahun 2011 kategori sangat tinggi diperoleh Kabupaten Serang. Namun, pada tahun 2012 kategori tersebut dimiliki oleh 
Kabupaten Tangerang dan Kota Tangerang Selatan. Seanjutnya, pada tahun 2013 kategori sangat tinggi diperoleh kembali oleh Kota Cilegon.

\section{Ketepatan Waktu}

Tepat waktu diartikan bahwa informasi harus disampaikan sedini mungkin untuk dapat digunakan sebagai dasar dalam membantu pengambilan keputusan-keputusan ekonomi dan untuk menghindari tertundanya pengambilan keputusan tersebut (Lestiani 2015). Peraturan Menteri Dalam Negeri (Permendagri) nomor 13 tahun 2006 menyebutkan bahwa Anggaran Pendapatan dan Belanja Daerah (APBD) merupakan dasar pengelolaan keuangan daerah dalam masa satu tahun anggaran dan ditetapkan paling lama satu bulan sebelum tahun anggaran yang bersangkutan dilaksanakan.

Persentase ketepatan waktu anggaran, pada tahun 2010 sampai 2012 terdapat $12,5 \%$ daerah yang masuk kategori rendah. Namun, setiap tahunnya terjadi perubahan daerah yang masuk kedalam kategori rendah. Pada tahun 2010 daerah yang masuk kategori rendah yaitu Kabupaten Lebak, hal ini terjadi karena adanya penurunan dibandingkan tahun sebelumnya pada ketepatan waktu penyampaian Perda APBD, ketepatan waktu laporan keuangan, ketepatan waktu penyampaian LPPD, dan kurangnya keberadaan Perda standar pelayanan publik.

Pada tahun 2011, Kota Tangerang masuk kategori rendah dikarenakan adanya penurunan pada ketepatan waktu penyampaian Perda APBD, ketepatan waktu laporan keuangan, ketepatan waktu penyampaian LPPD, kurangnya perda standar pelayanan publik serta kurangnya keberadaan standar operasional dan prosedur (SOP). Selanjutnya, pada tahun 2012 kota Serang masuk kategori rendah dikarenakan penurunan ketepatan waktu penyampaian laporan keuangan serta penyampaian LPPD.

\section{Transparansi dan Akuntabilitas}

Pengelolaan keuangan daerah yang transparan dan akuntabel menjadi suatu keharusan dikarenakan keuangan daerah bersumber dari pajak dan retribusi yang dibayarkan oleh masyarakat, sehingga pemerintah sebagai pemegang mandat harus menggunakannya untuk kesejahteraan masyarakat. Transparansi merujuk kepada sejauh mana masyarakat mengetahui dan dapat mengakses informasi terkait pengelolaan keuangan sesuai dengan pedoman dan rencana yang ditetapkan. Sementara akuntabilitas mengacu kepada sejauhmana anggaran direncanakan, digunakan, dipertanggungjawabkan, dan menghasilkan manfaat yang dibutuhkan masyarakat (Bappeda, 2013).

Persentase transparansi dan akuntabilitas menunjukkan bahwa kondisi transparansi dan akuntabilitas kabupaten/kota Provinsi Banten setiap tahunnya mengalami peningkatan, hanya pada tahun 2009 sebesar 12,5\% yang masuk kategori rendah yaitu Kabupaten Pandeglang. Berdasarkan pemeriksaan yang telah dilakukan Badan Pemeriksa Keuangan (BPK) atas Laporan Keuangan Pemerintah Kabupaten Pandeglang Tahun Anggaran (TA) 2009 menyimpulkan adanya pembatasan lingkung audit yaitu ketidakcukupan catatan akuntansi yang sangat material, sehingga BPK memberikan opini "Tidak Menyatakan Pendapat" atau Disclaimer (BPK, 2010). 


\section{Efektivitas Belanja}

Menurut Bappenas (2011)
efektivitas belanja daerah berkaitan
dengan apa yang dapat dihasilkan dari
belanja daerah. Perencanaan dan
penganggaran belanja daerah yang tidak
sesuai dengan kebutuhan daerah akan
menyebabkan underfinancing dan
overfinancing. Permasalahan yang akan
dihadapi ketika mengalami
underfinancing yaitu akan mengurangi
kapabilitas unit kerja dalam melaksanakan program yang sudah direncanakan sesuai dengan kebutuhan publik. Sedangkan permasalahan yang akan dihadapi ketika mengalami overfinancing yaitu pelaksanaan program tidak efisien dan tidak fokus dengan kebutuhan publik. Hal ini menyebabkan lemahnya efisiensi dan efektivitas unit kerja dalam melaksanakan program yang dibutuhkan publik dalam rangka menyejahterakan masyarakat (Juanda et al., 2013a).

Persentase efektivitas dari tahun 2009 sampai 2013 semakin efektif, tetapi pada tahun 2011 sampai 2013 daerah yang masuk kategori rendah sebesar $12,5 \%$ dan daerah yang masuk kategori rendah efektivitasnya berubah setiap tahunnya. Pada tahun 2011 Kota Cilegon masuk pada kategori rendah, sedangkan pada tahun 2012 Kabupaten Lebak masuk pada kategori rendah, selanjutnya tahun 2013 berubah menjadi Kota Serang yang masuk pada kategori rendah.

Menurut Susetyo et al. (2014) dalam mencapai tujuan pembangunan, diperlukan perencanaan yang cermat dalam pengeluaran pemerintah karena terbatasnya anggaran yang dimiliki oleh pemerintah. Selain itu juga, dalam mencapai kinerja pembangunan yang bagus tidak selamanya dengan menggunakan anggaran yang besar, karena menurut Adisasmita (2014) besarnya pengeluaran pemerintah belum tentu berakibat baik terhadap aktivitas perekonomian, sehingga sangat diperlukan efisiensi dalam pengeluaran pemerintah.

Gambar 3 menunjukkan kualitas belanja daerah kabupaten/kota Provinsi Banten. Kualitas belanja Kabupaten Lebak dan Kabupaten Pandeglang dari tahun 2009 sampai dengan tahun 2013 termasuk dalam kategori rendah. Hal ini terjadi karena rendahnya alokasi belanja daerah di Kabupaten Lebak dan Kabupaten Pandeglang. Kualitas belanja Kabupaten Serang masuk kepada kategori sangat tinggi pada tahun 2009, tetapi pada tahun 2010 sampai dengan tahun 2013 masuk kepada kategori tinggi.

Apabila dilihat dari lima kontruk kualitas belanja daerah, hampir semua kontruk belanja daerah Kabupaten Serang masuk dalam kategori tinggi dan sangat tinggi setiap tahunnya, hanya pada kontruk alokasi belanja daerah yang masuk kategori rendah pada tahun 2010 sampai dengan 2013. Selanjutnya, pada tahun 2009 kualitas belanja daerah Kabupaten Tangerang masuk kepada kategori sangat tinggi, dimana prioritas belanja, alokasi belanja dan efektivitas belanja masuk dalam kategori tinggi, sedangkan ketepatan waktu dan transparansi serta akuntabilitasnya masuk kepada kategori sangat tinggi. Sedangkan pada tahun 2010 sampai tahun 2012 kualitas belanja daerah Kabupaten Tangerang turun menjadi kategori sedang, dimana penurunan kategori ini seiringan dengan penurunan prioritas belanja daerah Kabupaten Pandeglang serta alokasi belanja. Kemudian pada tahun 2013, kualitas belanja Kabupaten Pandeglang kembali meningkat menjadi kategori tinggi, hal ini seiringan dengan meningkatnya semua kontruk kualitas belanja menjadi kategori tinggi dan sangat tinggi. 


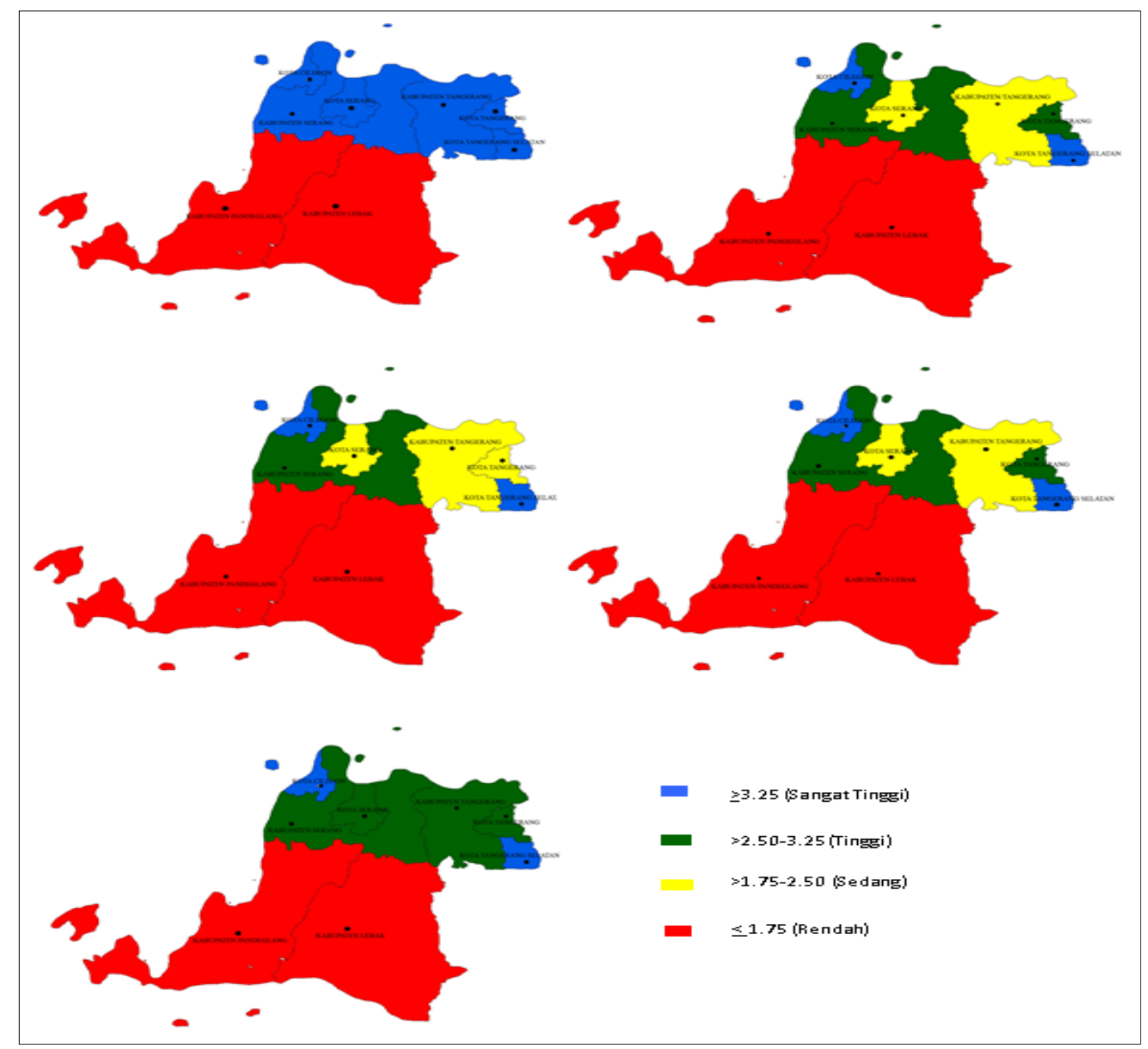

Gambar 3 Peta Kualitas Belanja Daerah Kabupaten/Kota di Provinsi Banten Tahun 2009-2013

Kualitas belanja daerah Kota Cilegon dari 2009 sampai 2013 masuk kategori sangat tinggi. Selanjutnya, Kota Tangerang pada tahun 2009 masuk kepada kategori sangat tinggi, tahun 2010, 2012 dan 2013 masuk kepada kategori tinggi, hanya pada tahun 2011 masuk kepada kategori sedang. Hal ini terjadi karena alokasi belanja dan ketepatan waktu masuk kepada kategori rendah, transparansi dan akuntabilitas masuk kepada kategori sedang.

Kualitas belanja daerah Kota Tangerang dari tahun 2009 sampai dengan 2013 hanya pada tahun 2011 masuk kepada kategori rendah, hal ini terjadi karena alokasi belanja dan ketepatan waktu masuk kepada kategori rendah. Kualitas belanja daerah Kota Serang pada tahun 2009 masuk kategori sangat tinggi, sedangkan tahun 2010 sampai tahun 2012 masuk kategori sedang. Pada tahun 2012, konstruk kualitas belanja Kota Serang yaitu prioritas belanja, alokasi belanja dan ketepatan waktu masuk kategori rendah. Kualitas belanja daerah Kota Tangerang Selatan pada tahun 2009 sampai dengan 
tahun 2013 masuk kategori sangat tinggi.

\section{Hubungan Kualitas Belanja dengan Kinerja Pembangunan Provinsi Banten}

Hasil estimasi dari model yang digunakan menunjukkan bahwa kualitas belanja daerah kabupaten/kota di Provinsi Banten memiliki hubungan positif dengan kinerja pembangunan dengan nilai indikator 0.678 . Pengaruh positif ini mengandung makna bahwa peningkatan kualitas belanja yang dilakukan oleh pemerintah daerah kabupaten/kota Provinsi Banten dapat meningkatkan kinerja pembangunan pada wilayah yang bersangkutan.

Demikian pula sebaliknya, dimana daerah kabupaten/kota yang memiliki kualitas belanja rendah cenderung lambat untuk meningkatkan kinerja pembangunannya. Pada hasil estimasi model, indikator yang mempengaruhi kinerja pembangunan yaitu indeks gini $(-0,784)$, Produk Domestik Regional Bruto (PDRB) per kapita $(0,685)$, dan Indeks Pembangunan Manusia (IPM) $(0,851)$. Ketiga indikator ini dilihat dari satu tahun setelah anggaran $(t+1)$.

Indeks gini sebagai indikator dari kinerja pembangunan mempunyai hubungan negatif dengan kualitas belanja daerah kabupaten/kota Provinsi Banten, mengandung makna bahwa ketika pemerintah daerah melakukan belanja semakin berkualitas dimana belanja dialokasikan berdasarkan prioritas pembangunan daerah yang dilakukan secara efisien dan efektif, tepat waktu, transparan dan akuntabel maka akan menurunkan ketimpangan pendapatan di masyarakat (Juanda et al. 2013a). PDRB per kapita dan IPM mempunyai hubungan positif dengan kualitas belanja, mengandung makna bahwa ketika belanja yang dilakukan pemerintah daerah semakin berkualitas maka akan meningkatkan PDRB per kapita dan IPM.

Kinerja pembangunan kabupaten atau kota Provinsi Banten pada tahun 2010 sampai 2014 dari hasil estimasi model dengan melihat nilai variabel laten. Kabupaten Lebak, Kabupaten Pandeglang dan Kabupaten Serang masuk kategori rendah. Oleh karena itu, pemerintah daerah kabupaten/kota provinsi Banten harus meningkatkan kualitas belanja daerah terutama di daerah Kabupaten Lebak dan Kabupaten Pandeglang agar tidak terjadi ketimpangan kinerja pembangunan antar kabupaten/kota Provinsi Banten.

\section{KESIMPULAN DAN SARAN}

\section{Kesimpulan}

Secara keseluruhan terpilih 21 indikator dari 40 indikator yang relevan mengukur kualitas belanja daerah kabupaten/kota Provinsi Banten. Selanjutnya, perubahan peta kualitas belanja dari tahun 2009 sampai 2013 menunjukkan bahwa kualitas belanja daerah Banten Utara (Kabupaten Tangerang, Kota Tangerang, Kota Tangerang Selatan, Kabupaten Serang, Kota Serang dan Kota Cilegon) lebih baik daripada Banten Selatan (Kabupaten Pandeglang dan Kabupaten Lebak).

Kabupaten Pandeglang dan Kabupaten Lebak mempunyai kualitas belanja yang rendah. Hal ini terjadi karena rendahnya alokasi belanja daerah di Kabupaten Lebak dan Kabupaten Pandeglang. Selain itu, proporsi alokasi belanja pegawai Kabupaten Pandeglang sekitar 50\% sampai 60\%, untuk Kabupaten Lebak sekitar $60 \%$ sampai $70 \%$. Sedangkan proporsi alokasi belanja modal Kabupaten Pandeglang hanya sekitar $6 \%$ sampai $17 \%$, dan 
untuk proporsi alokasi belanja modal Kabupaten Lebak hanya sekiat $18 \%$ sampai $28 \%$.

Peta kualitas belanja daerah Kota Serang, Kabupaten Serang, Kabupaten Tangerang dan Kota Tangerang Selatan mengalami penurunan kualitas belanja daerah dari kategori sangat tinggi pada tahun 2009, menjadi kategori tinggi pada tahun 2013. Hal ini juga disebabkan oleh menurunnya alokasi belanja daerah. Kualitas belanja daerah Kota Cilegon dan Kota Tangerang Selatan tetap dalam kondisi stabil menempati kategori sangat tinggi, hal ini disebabkan konstruk prioritas belanja, ketepatan waktu, alokasi belanja, akuntanbilitas dan transparansi serta efektivitas belanja rata-rata berada pada kategori tinggi dan sangat tinggi.

\section{Saran}

Berdasarkan hasil penelitian kualitas belanja daerah dan hubungannya dengan kinerja pembangunan di Provinsi Banten, maka saran yang dapat diberikan :

1. Kualitas belanja daerah yang rendah menghasilkan kinerja pembangunan daerah juga rendah. Kabupaten Lebak dan Kabupaten Pandeglang merupakan daerah tertinggal di Provinsi banten, pemerintah daerah harus meningkatkan alokasi belanja modal dengan dibangunnya lapangan pekerjaan yang padat karya untuk menyerap tenaga kerja dan meningkatkan pendapatan masyarakat.

2. Kabupaten/kota Provinsi Banten memiliki ketimpangan yang sangat tinggi baik dari sisi ketimpangan pendapatan, IPM, maupun PDRB per kapitan antara Banten Selatan (Kabupaten Lebak dan Kabupaten Pandeglang) dengan Banten Utara
(Kabupaten Tangerang, Kota Tangerang, Kota Tangerang Selatan, Kota Serang dan Kota Cilegon). Oleh karena itu, perlu adanya peningkatan kualitas belanja daerah di kabupaten/kota Provinsi Banten terutama Banten Selatan yang memiiki potensi daerah yang belum dimaksimalkan.

3. Pemerintah daerah Banten perlu meningkatkan transparansi data dan informasi yang dibutuhkan oleh publik terkait pengelolaan belanja daerah dan hasil dari pembangunan Provinsi Banten. Sehingga bisa membantu pemerintah daerah untuk kemajuan kinerja pembangunan di Provinsi Banten.

\section{DAFTAR PUSTAKA}

Adisasmita R. 2011. Pembiayaan Pembangunan Daerah. Yogyakarta (ID): Graha Ilmu.

Agustina A, Oesi. 2013. Analisis Kinerja Pengelolaan Keuangan Daerah dan Tingkat Kemandirian Daerah di Era Otonomi Daerah; Studi Kasus Malang. Ilmu Ekonomi Universitas Brawijaya

[Bappeda] Badan Perencanaan Pembangunan Daerah. 2013. Rencana Pembangunan Jangka Menengah Daerah. Serang (ID): BAPPEDA.

[Bappenas] Badan Perencanaan Pembangunan Nasional. 2011. Laporan Akhir Kajian Kualitas Belanja Anggaran Pendapatan dan Belanja Daerah (APBD). Jakarta (ID): Direktorat Otonomi Daerah.

[BPK] Badan Pemeriksa Keuangan. 2010. Penyerahan Laporan Hasil Pemeriksaan atas Laporan Keuangan Pemerintah Kabupaten Pandeglang TA 2009. Banten (ID): BPK RI. 
2015. Ikhtisar Hasil Pemeriksaan

Semester 1. Jakarta (ID): BPK RI

Dewi HS. 2015. Kinerja Pembangunan

Daerah : Suatu Evaluasi Terhadap Kursus Keuangan Daerah. Bogor. Tesis Pascasarjana Institut Pertanian Bogor (IPB)

Faguet JP. 2008. Decentralisation's Effect on Public Investment : Evidence and Policy Lessons From Bolivia and Coombia. Journal of Development Studies, 44 (8). Pp. 1100-1121

Hair J, Christian MR, Makro S. 2011. PLS-SEM : Indeed a Silver Bullet. Journal of Marketing Theory and Practice. 19(2). pp 139-152.

Hakim ML. 2013. Otonomi Daerah Dalam Krangka Negara Kesatuan Republik Indonesia (Studi Komparasi Otonomi Sebelum dan Sesudah Perubahan UUD 1945) [Skripsi]. Yogyakarta (ID): Universitas Negeri Sunan Kalijaga.

Heriwibowo D. 2016. Kajian Kualitas Belanja Daerah : Dinamika dan Pengukurannya Dalam Pembangunan Wilayah di Indonesia [disertasi]. Bogor (ID): Institut Pertanian Bogor.

Juanda B, Halim A, Azis N, Kaiwai HZ. 2013a. Evaluasi Regulasi Pengelolaan Keuangan Daerah dan Pengaruhnya Terhadap Upaya Peningkatan Kualitas Belanja Daerah. Robert A, Hefrizal H, editor. Jakarta (ID): Kementrian Keuangan RI.

Juanda B, Handra H, Auracher T, Sitepu B, Marthaleta N. 2013b. Penyusunan mekanisme Dana Alokasi Khusus (DAK) untuk pembiayaan Standar Pelayanan
Minima (SPM). Jakarta (ID): Kementrian Keuangan RI.

Juanda B. 2016. Reformasi Kebijakan Desentralisasi Fiskal Upaya Mendorong Pertumbuhan dan Mengurangi Kesenjangan Antardaerah. Radar Banten. Rubrik Opini : 2 (Kol 1-4),

Lestiani D. 2015. Ketepatan Waktu Penyampaian Laporan Keuangan dan Variabel-Variabel yang Mempengaruhi Terhadap Perusahaan Perbankan di Bursa Efek Indonesia Tahun 2011-2013 [skripsi]. Semarang (ID): Universitas Dian Nuswantoro Semarang.

Ostrom, Vincent, Charles M. Tiebout and Robert Warren. 1961. The Organization of Government in Metropolitan Areas : A Theoritical Inquiry. The American Political Science Review. 831842

Rondinelli, Dennis A. \& Nellis, John R. 1986. Assessing Decentralization Policies In Developing Countries : The Case for Cautious Optimism. Development Policy Review (SAGE, London, Beverly Hills and New Delhi), Vol. 4, 3-23

Susetyo IB, Domai T, Prasetyo WY. 2014. Kualitas Anggaran \& Belanja Daerah Terhadap Penyediaan Pelayanan Masyarakat Dalam Mendorong Percepatan Pem-bangunan Daerah Tertinggal (Studi di Kabupaten Lebak Provinsi Banten). Jurnal Administrasi Publik 2 3): 511-517. Todaro MP, Smith SC. 2006. Pembangunan Ekonomi. Jilid 1. Edisi 09. Benardi J, Saat S, Hardiani W, Editor. Jakarta: Penerbit Erlangga. 